\title{
Techniques Deployed by Spoken and Sign Language Public Service Interpreters: A Comparative Study
}

\author{
Agnieszka Biernacka \\ University of Warsaw \\ a.biernacka@uw.edu.pl
}

\author{
Aleksandra Kalata-Zawłocka \\ University of Warsaw \\ Association of Polish Sign Language Interpreters, STPJM \\ a.kalata@uw.edu.pl
}

\begin{abstract}
Deaf people are among those who, due to their insufficient knowledge of Polish, are compelled to use interpreting services in all settings. In order to exercise their right to full access to information within both public and private services, they need highly skilled sign language interpreters. These, however, have relatively limited opportunities of professional development and no possibility to pursue higher education in the area of sign language interpreting. In our paper a pioneer project, consisting in providing training opportunities for Polish Sign Language (PJM) interpreters on the use of strategies and techniques in public service interpreting, is presented. The study is based on a mixed-method approach combining a qualitative and quantitative analysis. In particular, the results of observations of the use of techniques in public service interpreting made during two, 3-hour each, training workshops organized for PJM interpreters are discussed, followed by the presentation of the results of a survey concerning the use of interpreting techniques carried out among the participants of the above two workshops. The results of both the observations and the survey have inspired many questions concerning an ethical aspect of both spoken and sign language interpreting techniques. Furthermore, a necessity to implement a project relating to further training and research, of which the discussed pilot project is a promising point of departure, has been confirmed.
\end{abstract}

Keywords: spoken language interpreting, sign language interpreting, interpreting techniques, community interpreting.

\section{Streszczenie}

Techniki używane w tłumaczeniu środowiskowym języka fonicznego i migowego. Studium porównawcze 
Osoby głuche, których znajomość języka polskiego jest niewystarczająca, sa zmuszone do korzystania z ustug tlumaczeniowych we wszystkich środowiskach. Wykonujac swoje prawo do petnego dostęu do informacji w instytucjach prywatnych i państwowych, potrzebuja wysoko wykwalifikowanych tlumaczy języka migowego. Ci jednak maja stosunkowo ograniczone możliwości rozwoju zawodowego oraz brak okazji do podejmowania studiów wyższych $w$ zakresie przekładu języka migowego. W niniejszym artykule przedstawiono pionierski projekt wdrażający cykl szkoleń dla tłumaczy Polskiego Języka Migowego (PJM) na temat strategii i technik w tlumaczeniu środowiskowym. Badanie składa się z analizy jakościowej i ilościowej. Analiza jakościowa polega na obserwacji zastosowania technik w tlumaczeniu środowiskowym przeprowadzonej $w$ trakcie dwóch 3-godzinnych sesji warsztatowych zorganizowanych dla tłumaczy PJM, natomiast analiza ilościowa obejmuje badanie ankietowe przeprowadzone wśród uczestników tych warsztatów po zakończeniu obydwu sesji. Wyniki obserwacji i ankiet doprowadzity do powstania wielu nowych pytań dotyczacych etycznego aspektu technik $w$ tłumaczeniu języków fonicznych i migowych. Ponadto, potwierdzono konieczność wdrożenia projektu obejmujacego dalsze szkolenia i badania, których obiecującym punktem wyjścia jest omówiony tutaj projekt pilotażowy.

Keywords: thumaczenie ustne, thumaczenie języka migowego, techniki thumaczenia ustnego, tlumaczenie środowiskowe.

\section{Introduction}

The awareness of spoken language interpreters as regards strategies and techniques, as well as their classifications, denominations, effectiveness, and didactics is well rooted among scholars in Translation Studies and constitutes an inseparable component of the interpreter's competences (Kalina 1992; Gile 1995; Wadensjö 1998; Riccardi 1998; Bartłomiejczyk 2004; Tryuk 2007, 2010). A scholarly discussion related to strategies and techniques deployed in sign language interpreting is not that extensive (Llewellyn-Jones 1981; Cokely 1986; Napier 2005) and sometimes, as in the context of Polish Sign Language, has yet to begin.

Deaf people are among those who, due to their insufficient knowledge of Polish, are in need of interpreting services in all sorts of settings. ISO 13611: 2014 Interpreting - Guidelines for community interpreting establishes criteria and recommendations for community interpreting during oral and signed communication that enables access to services for people who have limited proficiency in the language of such services. ${ }^{1}$ Although the norm provides for equal respect towards spoken and sign language interpreters, the legal framework for both is different. Namely, Art. 2.2. of the Act of 25 November 2004 on the Profession of Sworn

\footnotetext{
${ }^{1}$ https://www.iso.org/standard/54082.html (date of access: April 11, 2019).
} 
Translator $^{2}$ - governing the profession of public service translators and interpreters in Poland - expressly sets forth that the Act shall not apply to sign language interpreters and translators of communication systems other than natural languages. And in spite of the fact that Polish Sign Language is considered a fully-fledged, natural language by linguists and researchers (Farris 1994; Świdziński 1998; Tomaszewski and Rosik 2003), it has not been officially recognized as such at a legislative level. The work of sign language interpreters in legal settings is thus regulated by the Regulation of the Minister of Justice of 24 January 2005 on court experts $^{3}$.

In order to exercise their right to full access to information in all settings within both public and private sectors, deaf people require highly skilled sign language interpreters, who, however, have relatively limited opportunities for professional development and no possibility to pursue higher education in the area of sign language interpreting.

In this paper the results of a pioneer comparative study of techniques deployed by spoken and sign language public service interpreters are presented. The study is based on a mixedmethod approach combining a qualitative and quantitative research approaches (Creswell 2014; Dörnyei 2007). In particular, the results of observations of the use of techniques in public service interpreting made during two, 3-hour each, training workshops organized for Polish Sign Language (PJM) interpreters are discussed, followed by the presentation of the results of a survey concerning the use of interpreting techniques carried out among the participants of the above two workshops. $^{4}$

The aim of the study is, first, to contribute to PJM interpreters' lifelong learning opportunities, second, to transfer knowledge of techniques deployed by spoken language interpreters, third, to compare the interpreting decisions made by interpreters of spoken and sign language, and forth, to analyze these decisions from the point of view of professional ethics. The study is the first stage of a non-profit project implementing an integrated approach to bilateral interpreting for spoken and sign language interpreting (Integrated Approach to Spoken and Sign Language Interpreting, IASSLI).

\footnotetext{
${ }^{2}$ Ustawa o zawodzie tłumacza przysięgłego z dnia 25 listopada 2004 r. (Dz.U. z 2015 r. Nr 487) https://bip.ms.gov.pl/pl/rejestry-i-ewidencje/tlumacze-przysiegli/ (date of access: July 7, 2019).

${ }^{3}$ Rozporządzenie Ministra Sprawiedliwości z dnia 24 stycznia 2005 r. o biegłych sądowych http://prawo.sejm.gov.pl/isap.nsf/DocDetails.xsp?id=WDU20050150133 (available only in Polish, date of access: February 5, 2019).

${ }^{4}$ Although the project referred to in this paper relates to both techniques and strategies in public service interpreting, the analysis herein presented focuses on interpreting techniques while interpreting strategies need to be subject to further research and a separate analysis to be discussed in a subsequent paper.
} 


\section{Accuracy and impartiality as fundamental principles of the interpreter's professional ethics}

Ethical principles of accuracy and impartiality binding upon spoken and sign language interpreters contribute to making a non-Polish speaking interlocutor understand and be understood.

The ethical guidelines recommended equally to sworn translators, court interpreters, and public service interpreters of spoken languages in all settings is the Polish Sworn Translator's Professional Code; $\S 17$ of the document provides for accurate interpreting defined as the one "rendering a form, content, and style of the source message, without adding, omitting, or modifying" any information, while $\S 75$ proposes "preserving a grammatical form of the source message". Moreover, $\S 4$ recommends that while performing their duties, interpreters should "not express their own opinions"5. Therefore, from a normative point of view, the interpreter is a "faithful renderer of the original utterances" (Hale 2008: 102).

As regards PJM interpreters, the ethical framework of interpreting in all types of settings, legal being one of them, is established by the Code of Ethics developed by the Association of Polish Sign Language Interpreters (STPJM). The need for precision of interpreting is mentioned in the section on PROFESSIONALISM stating that precision is to be achieved by "conveying content as well as the spirit of what is being communicated by the use of language that is best understood by the consumer". It is also emphasized in the section on IMPARTIALITY that postulates, ,refraining oneself from intentional modifications of the original meaning due to one's own views". 6

Alongside effective rendition of exchanged utterances, a compliance with ethical principles is viewed in this paper as indispensable for the success of interpreted communication. Thus, it is used as the main criterion for evaluation of interpreting strategies and techniques.

\footnotetext{
${ }^{5}$ Kodeks zawodowy tłumacza przysięgłego http://tepis.org.pl/wp-content/uploads/Kodeks-zawodowyt\%C5\%82umacza-przysi\%C4\%99g\%C5\%82ego-2018.pdf (available only in Polish, the quotations from the document have been translated into English for the purposes of this paper by the authors, date of access: December 4, 2018).

${ }^{6}$ Kodeks Etyczny Stowarzyszenia Tłumaczy Polskiego Języka Migowego http://nowy.stpjm.org.pl/wpcontent/uploads/2016/11/kodeks.pdf (available only in Polish, the quotations from the document have been translated into English for the purposes of this paper by the authors, date of access: April 11, 2019).
} 


\section{Method and design of the workshops}

The pilot project, the results of which are presented in this paper, was composed of two, 3-hour each, interactive (Q\&A) workshop sessions concerning the use of interpreting strategies and techniques in public service interpreting organized for Polish Sign Language interpreters held on 26 February and 20 May 2018 in Warsaw.

Both sessions were attended by hearing and deaf interpreters of PJM, all of them active on the professional market. 10 ( 3 deaf and 7 hearing) interpreters of PJM attended the first session titled "Strategies and techniques in bilateral interpreting - between theory and practice", while in the second session titled "Bilateral interpreting - practical approach" 19 (6 deaf and 13 hearing) interpreters of PJM participated. In both groups professional experience of interpreters ranged from 1 to 20 years (see Figure 3). In order to make the two sessions accessible to the deaf attendants, interpreting to PJM was ensured.

The first session covered a theoretical component, during which the participants became acquainted with strategies and techniques in spoken language interpreting, and a practical component, within which they learnt how to identify, distinguish, apply, and assess from the point of view of professional ethics the strategies and techniques. All the examples shown and discussed during the workshops were transcriptions of naturally occurring data in legal setting, which formed part of the material collected in the years 2006-2008 (Polish-Spanish real communicative acts) and 2014-2015 (Polish-Spanish and Polish-English real communicative acts) for the purposes of the research into court interpreting. The fragments of court trials were chosen deliberately due to the fact that court interpreting, which consists mostly in bilateral interpreting, is secured with the most rigorous principles of professional ethics. It was assumed that the fragments were supposed to categorically show the strategies and techniques, as well as to facilitate identification of both positive and negative interpreting decisions.

The second session was of a practical nature: after a short debriefing of a theoretical component presented during the first session, the interpreters of PJM interpreted short fragments of communicative acts in different (medical, administrative, legal) settings, discussed and justified their decisions, as well as similarities of and differences between the strategies and techniques applied by spoken and PJM interpreters. Afterwards, the attendants participated in role-play activities according to the instructions provided by the authors of this paper. The first, 5-minute 25-second long, role-play was meant as a communicative act in which 3 persons participated: two interpreters participating in the session, one of whom played a role of a deaf client of a passport office who wanted to have a new passport issued, and the 
other was the interpreter of PJM, while the organizer, i.e. one of the authors, played a role of the office worker. The second, 11-minute long, activity was meant as a communicative event in which a sale of a water mill was negotiated; 3 persons participated (two participants of the session: a deaf interpreter who played a role of a buyer, an interpreter from and into PJM, and the trainer, i.e. the other author, who played a role of a seller of the water mill).

Both sessions were audio- and video- recorded upon prior written consent granted by all the attendants. In addition, during each session, observations of the participants' discussions and activities were made. After the second session a survey was carried out, the purpose of which was, first, to measure the level of the participants' satisfaction with the training, and second, to obtain feedback concerning the content of the workshop, check the participants' awareness of interpreting techniques, as well as canvass possible needs for further training in the field.

The aim of the project was to compare the decisions concerning strategies and techniques made by interpreters of spoken and sign languages, as well as to discuss these decisions from the point of view of professional ethics. However, it should be taken into account that the nature of the examples of spoken language and sign language interpreting presented in the paper is slightly different. While the spoken language examples come from real-life communicative events interpreted by professional court interpreters in the course of their work, the sign language examples come from pre-arranged role-plays, during which the participants performed ad hoc interpretations, without prior preparation concerning the content, for the purposes of the interpreter training.

\section{Results of the observation}

Within the practical component of the workshop sessions, on the basis of naturally occurring data, the attendants were instructed about interpreting techniques for spoken languages, as classified for bilateral interpreting by Wadensjö ("renditions", 1998: 108), namely: close rendition (“duplication”, Koskela, Koskinen, and Pilke 2017: 474), expanded rendition (“extended rendition”, Biernacka 2019: 92), reduced rendition, substituted rendition, summarized rendition (“condensation”, Koskela, Koskinen, and Pilke 2017: 474), two-part or multi-part rendition, non-rendition, and zero rendition. This classification has been chosen for training purposes for two reasons: first, as opposed to other techniques, it has been created on the basis of the interpreter's decisions in bilateral interpreting in police setting, thus it illustrates 
and denominates the techniques actually deployed in specialized interpreting; and secondly, the catalogue of these techniques is short, and the boundaries between the techniques are clear.

The results of observations are presented according to the technique used in a particular communicative event. First, for illustrative purposes, an example of a spoken language interpreting is provided, followed by a fragment of the role-play activities of sign language interpreters during the second workshop. All the examples are enriched with the 'Authors' translations' into English presented in curly brackets after an utterance in Polish or PJM.

The analysis is to show similarities of and differences between deployment of techniques in interpreting spoken and sign languages with a special emphasis put on accuracy and impartiality as fundamental principles of ethics of interpreters.

\subsection{Close renditions}

Close rendition (Wadensjö 1998: 108; Biernacka 2019: 92; “duplication”, Koskela, Koskinen, and Pilke 2017: 474) means that the interpreter renders the sense of the original utterance without adding, omitting or modifying the content of the utterance. It seems then, that applying this technique satisfies the recommendations of $\S 17$ of the Sworn Translator's Professional $\operatorname{Code}^{7}$ concerning accuracy in interpreting:

(1) Close renditions in spoken language interpreting

Judge: Czy ten stan takiego braku zrozumienia uległ pogorszeniu czy uległ poprawie?

\{Did this condition of lack of understanding got worse or better?\}

Interpreter: Did this condition of lack of understanding got worse or better?

Witness: No, it got worse.

Interpreter: Nie, pogorszył się. \{No, it got worse.\}

As shown in Example (1), close renditions are deployed when short question-answer couplets including simple syntax and limited vocabulary are rendered.

As observed during the workshop role-plays and according to the attendants of both workshops, PJM interpreters, alike spoken language interpreters, strive to deploy close rendition whenever possible, i.e. when original utterances are relatively short and when spoken language terms have their lexical equivalents in PJM:

\footnotetext{
${ }^{7}$ Kodeks zawodowy thumacza przysięgłego http://tepis.org.pl/wp-content/uploads/Kodeks-zawodowyt\%C5\%82umacza-przysi\%C4\%99g\%C5\%82ego-2018.pdf (date of access: December 4, 2018).
} 
(2) Close renditions in sign language interpreting

Clerk: I jeszcze orzeczenie o niepełnosprawności. \{And also a certificate of disability. \} Interpreter: [also] [point. pronoun YOU] [certificate + paper] [disability] \{Also your certificate of disability.

In situations when there is no lexical equivalent of a spoken term in PJM, in particular when the term is highly specialized, PJM interpreters resort to a technique known as fingerspelling they represent the word of spoken language by means of a hand alphabet. ${ }^{8}$ Unlike in spoken languages, in sign languages this technique is well-known and deployed (cf. Nicodemus and Emmorey 2013) as illustrated by Example (3):

(3) Close renditions in sign language interpreting

Seller: ...akurat to koło wodne jest nasiębierne. $\{\ldots$...and this water wheel is the overshot one.\}

Interpreter: [point. THIS] [wheel] O-V-E-R-S-H-O-T \{ This wheel is o-v-e-r-s-h-o-t... $\}$

The technique of fingerspelling facilitates conveying spoken language terms absent in sign languages. It enables the interpreter to visualize the term that was used by the speaker, but without conveying its meaning. Similarly, when the PJM equivalent of a spoken word has more than one meaning, and for some reason it is crucial for the deaf interlocutor to know which exactly meaning the hearing interlocutor is referring to by using this word. Fingerspelling serves enhancing the precision of the sign used by the interpreter. In both cases, however, the precision is achieved merely at the textual level of the utterance.

\subsection{Extended renditions}

Extended rendition (Biernacka 2019: 92; “expanded rendition”, Wadensjö 1998: 108) consists in adding, by the interpreter, the elements absent in the original utterance:

(4) Extended renditions in spoken language interpreting

\footnotetext{
${ }^{8}$ Fingerspelling is applied in signed utterances to transfer names, proper names, toponyms, specialized terminology, loan words etc. (Sutton-Spence and Woll, 1999)
} 
Witness: And they say that they will check.

Interpreter: Pan prezes ... powiedział, że sprawdzi. \{Mr President... said that he would check.

In the event of spoken language interpreting, extended renditions may consist in changing a style from direct into indirect sentences. If this is the case, which probably results from the interpreter's knowledge of the context, such modification can be perceived as infringing $§ 75$ of the Sworn Translator's Professional Code imposing a preservation of a grammatical form of the original utterance, in particular, as regards a grammatical person.

As far as PJM interpreting is concerned, the technique of extended rendition was observed on a few occasions in the role-plays. In Example (5) the interpreter added I am sorry and what it looks like:

(5) Extended renditions in sign language interpreting

Seller: I tu się Pan myli, bo Pan tego nie wie! \{And here you are mistaken, because you do not know it!

Interpreter: [but] [sorry] [point. pronoun YOU] [mistake] [not know] [what it looks like] \{And, I am sorry, you are mistaken, you do not know what it is like.

However firm the original Polish utterance may appear in its textual level, its tone is rather humorous. But presumably, the prosodic elements of the utterance are not fully received by the deaf person, thus the interpreter decides to convey them by adding I am sorry to soften her translation.

The addition of what it looks like (jak wyglada) was probably a result of interpreting the previous sentence in which the same phrase appeared. It may be assumed that the interpreter repeats the phrase to make her translation more precise. Apparently, she decides that the second part of the original utterance because you do not know it may be unclear to the deaf person and she specifies what the pronoun it refers to. This expansion, however, does not influence the pragmatic content of her utterance.

Expanded rendition is undoubtedly deployed in situations when interpreted communication is accompanied or interrupted by external sounds the hearing interlocutors can receive or of which they are aware in contrast with the deaf ones, such as the car horn blowing 
outside the window or a doorbell or telephone ringing. The sounds may affect the hearing interlocutor's reactions and behaviours, but the deaf interlocutor may be unaware of them. No specific sounds interfered with the role-plays so there was no need for interpreters to deploy this type of the expanded rendition then, but this is what sign language interpreters tend to do in similar situations.

\subsection{Reduced renditions}

Reduced rendition (Wadensjö 1998: 108; Biernacka 2019: 92) is described as reducing, by the interpreter, of the content of the original utterance:

(6) Reduced renditions in spoken language interpreting

Judge: Ale nie mówi pan po polsku? \{But you don’t speak Polish?\}

Interpreter: But you don't speak Polish?

Respondent: I wish I did.

Interpreter: Nie, nie mówi pan po polsku. \{No, he doesn't speak Polish $\}$

Judge: Tylko czyta po polsku? \{You only read in Polish?\}

Interpreter: Do you read in Polish?

In the case of spoken language interpreting, reduction may involve eliminating ironic, sarcastic, or in other way emotionally loaded original utterances. As shown in Example (6), the respondent answers I wish I did to the judge's questions whether the respondent speaks Polish. Instead of providing a close rendition, the interpreter transmits the respondent's statement as No, he doesn't speak Polish. Although the general message (that the respondent does not speak Polish) is preserved, what is omitted is certain sarcasm contained in the answer, which can be detected on the basis of the premises relating to the formal context of the communicative act. First, the context of the courtroom requires that the party, when asked by the judge, answers a general question by simply saying Yes, I do or No, I don't. In the presented interaction the respondent indeed answers the judge's question, but also expresses his regret concerning the fact that he does not speak Polish; therefore, the respondent's response conveys both the answer and the emotional comment, the latter, however, is not reflected in the interpreter's rendition. It seems thus that in Example (6) reduced rendition is in contradiction to $§ 17$ of the Sworn Translator's Professional Code recommending preserving the whole content, including the style, of the original utterance. 
As regards PJM interpreting, the analyzed material provided several examples of at least three types of reduced renditions. In Example (7) the reduction is related to prosodic layer of the original utterance:

(7) Reduced renditions in sign language interpreting

Clerk [sounding irritated]: Gdzie Pani zrobili takie zdjęcie? \{Where did they take you such a photo?\}

Interpreter [neutrally]: [where] [take photo] [who] [raising shoulders - quest.] \{Where was the photo taken, by whom?\}

The question asked by the clerk with visible irritation is conveyed as more neutral to the deaf person. It should be done by means of intensified facial expression reflecting the tone and the emotions of the clerk. The deaf person may not perceive the clerk as unpleasant. On the other hand, the interpreter may assume that the emotional reactions of the clerk are visible enough for the deaf person and enhancing them is redundant.

In Example (8) the reduced rendition appears to be context-based.

(8) Reduced renditions in sign language interpreting

Seller: Bardzo się cieszę, że Państwo zdecydowali się kupić ten młyn. \{I am very glad you (both) decided to buy this mill.\}

Interpreter: [glad] [point. pronoun YOU (sing.)] [want] [buy] [mill] [water] \{I am glad you want to buy the water mill.\}

The owner of the mill is convinced that the two people who came to meet her are both interested in buying the mill. That is why she addresses both of them in her welcoming utterance. However, the interpreter, being fully aware of her role in the interaction, interprets the utterance addressing only the deaf person immediately.

Example (9) illustrates the reduced rendition at the discursive and stylistic levels:

(9) Reduced renditions in sign language interpreting 
Seller: Po prostu wybudowanie w ogóle takiego młyna $\mathrm{z}$ takim kołem wymaga olbrzymiej znajomości właśnie inżynierii wodnej. \{lt is just that building such a mill generally requires enormous expertise precisely in water engineering.

Interpreter: [point. THIS] [already] [point. THIS] [mill] [build] [must] [who] [know] [expert] \{Building this mill requires expert knowledge.

The main intention of the seller's utterance is conveyed in the target message, however certain stylistic modifications were introduced to it that make it sound firmer and simpler.

The discussion that followed the role-play did not result in any explicit explanations as to why the interpreter applied reduced rendition in the abovementioned situation. It may be assumed that, to some extent, the decision was caused by the element of surprise, as the interpreter was not prepared for the task - she was not familiar with the domain of interpreting. This might have evoked the feeling of discomfort which, in turn, might have been doubled by the fact that the role-play was observed (and evaluated) by other participants of the workshop, themselves being PJM interpreters. Eventually, the interpreter admitted that her decision to reduce some of the utterances stemmed from the time pressure caused by the need to interpret the eloquent, flamboyant and sometimes lengthy utterances of the seller. Consequently, some elements of such utterances might have been considered redundant by her, at least in the context of the overall meaning of the message.

\subsection{Substituted renditions}

Substituted rendition (Wadensjö 1998: 108; Biernacka 2019: 92) consists in applying both extended and reduced renditions, therefore the interpreter enriches certain fragment(s) of the original utterance, while reducing some other elements, which they deem unnecessary:

(10) Substituted renditions in spoken language interpreting

Witness: She told me that she needed time to reset.

Interpreter: Powiedziała, że potrzebowała czasu, żeby się jakby zresetować. \{She said she needed time to sort of reset.

As shown in Example (10), the interpreter applies a substituted rendition when she inserts a discourse marker sort of (jakby), by which she reduces a pragmatic meaning of the subsequent verb reset. In other words, the original speaker states that his wife needed time to reset, but the 
interpreter softens the information. The use of the discourse marker can be explained by the fact that the verb reset transferred to the Polish language belongs to both computer jargon and colloquial language, but does not appear in standard Polish. In this case, substituted rendition can be understood as contradictory to $\S 17$ of the Sworn Translator's Professional Code where it is set forth that no modifications in the interpretation of original utterances are admitted.

As far as PJM interpreting is concerned, the technique of substituted rendition was not observed in the analyzed role-plays.

\subsection{Summarized renditions}

Summarized rendition (Wadensjö 1998: 108; Biernacka 2019: 92; “condensation”, Koskela, Koskinen, and Pilke 2017: 474) is defined as transmitting by the interpreter the sense of the original utterances so that the rendition is a summary rather than a translation of the original utterance:

(11) Summarized renditions in spoken language interpreting

Judge: W tym miejscu thumacz... na zarządzenie przewodniczącego opuszcza salę rozpraw. To wszystko. Może pan opuścić salę rozpraw. \{Here the interpreter... by an order of the President leaves the courtroom. That is all. You can leave the courtroom.\} Interpreter: You can go. \{Może pan iść.\}

The judge informs the witness that he can leave the courtroom. Nonetheless, to make the hearing more solemn and to adjust to the court style, the judge makes references to the presiding judge's order. The spoken interpreter omits this fragment of the judge's utterance and summarizes the content by transmitting only the basic information that the witness can go. From the ethical point of view such technique can be assessed as infringing $\S 17$ of the Sworn Translator's Professional Code recommending interpretation of the whole original message without introducing any changes. However, there are instances of the act of communication where the exchange between the main speakers is so fast that the interpreter is not able to provide close renditions and needs to resort to summarizing the original content; in other words, the interpreter strives for maintaining a non-Polish speaking witness "linguistically present" (Gentile et al. 1996: 98).

The summarized rendition as deployed by PJM interpreters was not observed in the analyzed material, however, in the course of discussions following each of the role-plays some 
of the workshop attendants admitted that they had happened to apply this technique in their professional practice due to the reasons mentioned above with respect to spoken language interpreting.

\subsection{Two-part or multi-part renditions}

Two-part or multi-part rendition (Wadensjö 1998: 108; Biernacka 2019: 92) means that the interpreter changes complex statements of primary speakers into simple sentences:

(12) Two-part renditions in spoken language interpreting

Witness: Yes, the Bank didn't have any objections to our work at all.

Interpreter: Tak, Bank nie miał żadnych zastrzeżeń. Do naszej pracy. \{Yes, the Bank didn't have any objections. To our work.\}

The interpreter precisely renders the content of the original message. The only difference between the witness' and the interpreter's utterances is that the former produces one statement while the latter expresses the same in two statements. Example (12) shows that a two-part rendition can be conducive to satisfying, by the interpreter, the recommendations of $\S 17$ of the Sworn Translator's Professional Code concerning an ethical principle of accuracy. In other words, the interpreter conveys a full meaning of the original utterance.

As regards PJM interpreting, two-part or multi-part renditions were not observed in the role-plays.

\subsection{Non-renditions}

Non-renditions (Wadensjö 1998: 108; Biernacka 2019: 92) are the interpreter's own statements:

(13) Non-renditions in spoken language interpreting

Witness: And my experience so far well, she's already told you everything, you need to know: no contact, that's her wish, no contacts...

Interpreter: A moje doświadczenie jest takie, tak jak ona powiedziała, tłumaczę dosłownie, czyli, tak jak... powiedziała... przed..., przede mną, żadnych 
kontaktów... \{And my experience is like she's already said, I'm interpreting literally, that is, like... she's said... before... before me, no contacts...\}

In Example (13) the interpreter inserts a comment I'm interpreting literally, that is, like she 's... said, the aim of which is probably indicating how the interpreter understands the ethical principle of accuracy and that he complies with this rule. In the case of spoken language interpreting, non-renditions can be produced by the interpreter when they consider it is necessary to inform the parties of a problem in the act of communication, such as, e.g. lack of audibility ( $\$ 73$ of the Sworn Translator's Professional Code), a request to repeat the utterance ( $\$ 76$ of the Sworn Translator's Professional Code), or a need to explain a specialized lexical term ( $\$ 80$ of the Sworn Translator's Professional Code). As a rule, the recommendations of the Sworn Translator's Professional Code are an exhaustive catalogue of possible circumstances, in which the interpreter is allowed to apply non-renditions.

With respect to sign language interpreting, at least two types of non-renditions were identified in the role-plays. The first one, illustrated by Example (14) below refers to a situation that appears to be fairly common in interpreted communication in which deaf people participate:

(14) Non-renditions in sign language interpreting

Clerk: Ale o co chodzi? \{But what is going on?\}

Interpreter: [reason] \{What is going on?\} Przepraszam, ale przestawiłam krzesła, żeby móc widzieć głuchą osobę, gdy będę jej tłumaczyła to, co Pani mówi. \{I am sorry, but I rearranged the chairs so that I could see the deaf person while interpreting what you say.

Being responsible for maintaining eye contact with her deaf consumers, the interpreter devotes the first moments of the role-play to rearrange her chair to ensure herself appropriate visual contact with the deaf person as well as auditory contact with the clerk. As she hears the question of the clerk, she provides her explanation, at the same time trying to interpret her utterance to the deaf person.

In Example (15) below, the first part of the interpreter's own utterance results from her apparent unfamiliarity with the specialized term used by the seller of the mill: 
(15) Non-renditions in sign language interpreting

Seller: Jest to koło nasiębierne. \{This wheel is the overshot one.\}

Interpreter (look of surprise at the seller): [sorry] [point. pronoun I] [not know] [explain] [point. THIS] [lady] [say] O-V-E-R-S-H-O-T. [point. pronoun I] [not know] [word]. [point. pronoun YOU] [know] [reason + quest.] [I am sorry, but I do not know how to explain what the lady is saying. She says "overshot". I do not know this word. Do you know what it is about?\}

Deaf buyer: [please] [repeat] \{Please repeat.\}

Interpreter: [point. pronoun SHE] [point. pronoun I] [quest.] [who] [repeat] [quest.] Her or me? Who should repeat?

The interpreter decides to inform the deaf participant of communication about her inability to interpret the unknown term. She fingerspells it, so that the deaf person knew which term exactly is the problem. She also asks the deaf person whether he knows the term. In response, the deaf person asks the interpreter to repeat, but she does not know whether it is her who should repeat her utterance or the hearing participant. Thus, she formulates another utterance of her own asking the deaf person to clarify whose utterance should be repeated. The second time the interpreter does not provide rendition of either of the participants of the communication act, but formulates her own utterance that serves to refine the intention of the deaf buyer.

\subsection{Zero renditions}

Zero rendition (Wadensjö 1998: 108; Biernacka 2019: 92) consists in a complete omission by the interpreter of the information contained in the original utterance:

(16) Zero renditions in spoken language interpreting

Witness: Anything else stupid to say?

Interpreter: [silence]

As regards spoken language interpreting, Example (16) presents an episode of interaction where the interpreter produces a zero rendition after the witness refers to the judge with a question, which is probably considered impolite by the interpreter. Therefore, she prefers to 
remain silent. It seems that zero renditions can be assessed as infringing the principle of accurate interpreting as set forth in $§ 17$ of the Sworn Translator's Professional Code.

As far as PJM interpreting is concerned, at least one example of zero renditions (Example (17)) was identified in the observed role-plays:

(17)Zero renditions in sign language interpreting

Deaf buyer: [nie] [źle] [powiedzieć] \{No, I was incorrect.\}

Interpreter: [no interpreting]

Deaf buyer: [źle] [powiedzieć] \{I was incorrect.\}

Interpreter: [no interpreting]

Deaf buyer: [źle] [powiedzieć] \{I was incorrect.\}

Interpreter: I am sorry, I was incorrect.

The analysis of a longer fragment of communication in which this example of zero rendition was traced allows to assume that the lack of interpreting is caused by the interpreter's inability to coordinate the interaction. The interpreter ignores two utterances of the deaf person, evidently focusing on conveying utterances of the hearing person. It is fairly noticeable that she is struggling with the upcoming flow of the hearing person's eloquent monologue. Although only after the third repetition, the rendition of the deaf person's utterance is finally provided.

\section{Results of the post-workshop survey}

The discussions during and after the first workshop session showed a strong need for providing the subsequent workshop, during which the participants, based on the knowledge of strategies and techniques gained at the first training session, could practice their skills, share ideas and exchange expertise, all under the supervision of the trainer. Thus, the attendants of the second workshop session were asked to respond to a survey, the results of which are presented below, and which was divided into three parts: (1) the participant's professional profile, (2) the participant's satisfaction with the workshops and their need for further training, and (3) checking the participant's post-training awareness of the ethical load of interpreting techniques. 


\subsection{Participants' professional profile}

13 respondents sent back the completed forms. 4 of them were deaf and 9 were hearing (see Figure 1).

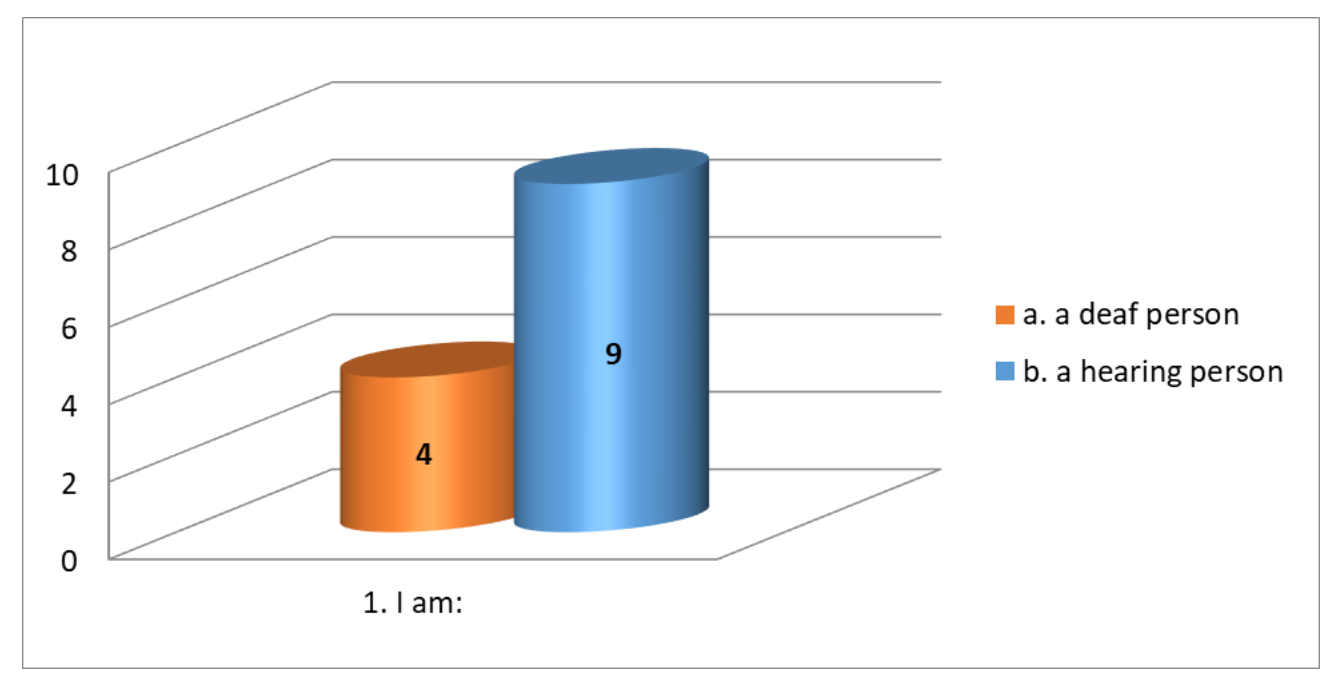

Figure 1. Deaf and hearing attendants of the 2 nd training session

As regards professional experience of the attendants, out of all the 13 respondents, 2 have been working as PJM interpreters for up to 5 years, 5 of them for 5 to 10 years, 1 for 10 to 15 years, 3 for 15 to 20 years, while 2 did not currently work as interpreters (see Figure 2).

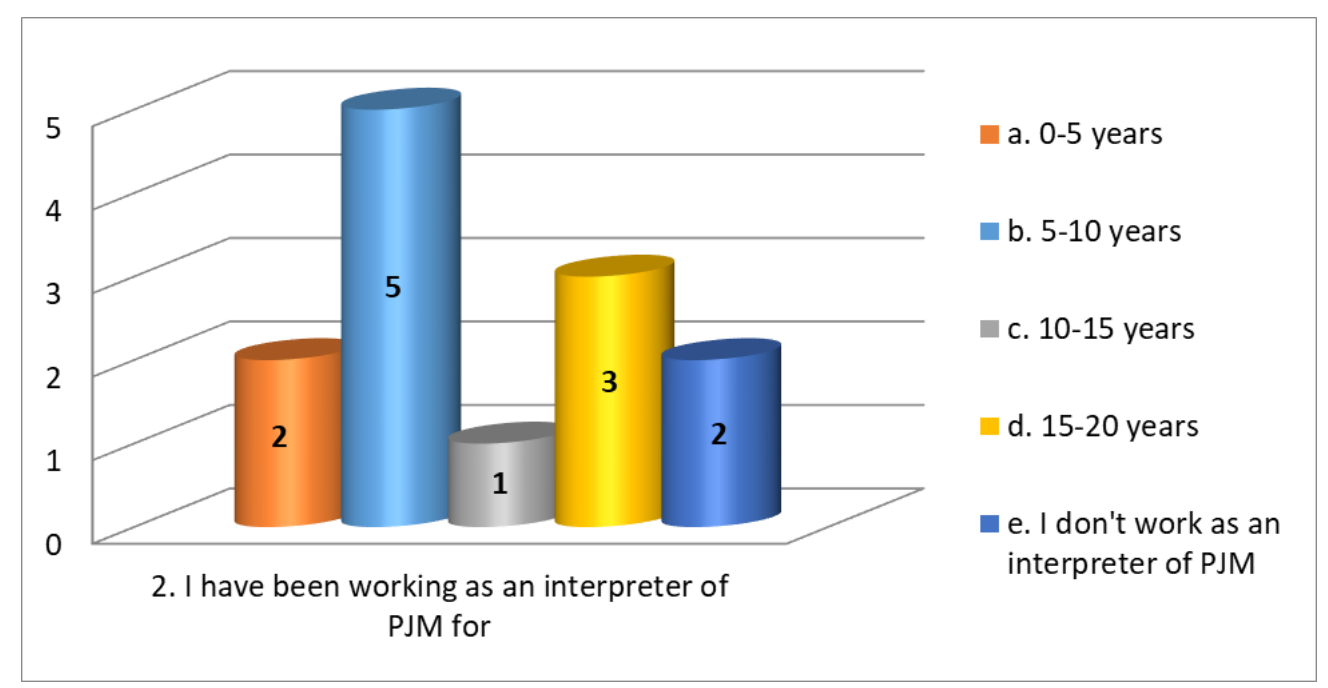

Figure 2. The attendants' seniority as interpreters

Interestingly, deaf persons represent all ranges except the group of the longest seniority, to which only hearing interpreters belong. It stems from the fact that the concept of deaf interpreter is relatively new, not only in Poland. 
As far as frequency of providing public service interpreting, 2 attendants did public service interpreting everyday, 5 once to several times a week, 3 once to several times a month, 1 once to several times a year, 2 respondents did public service interpreting accidentally at the workplace or occasionally (see Figure 3).

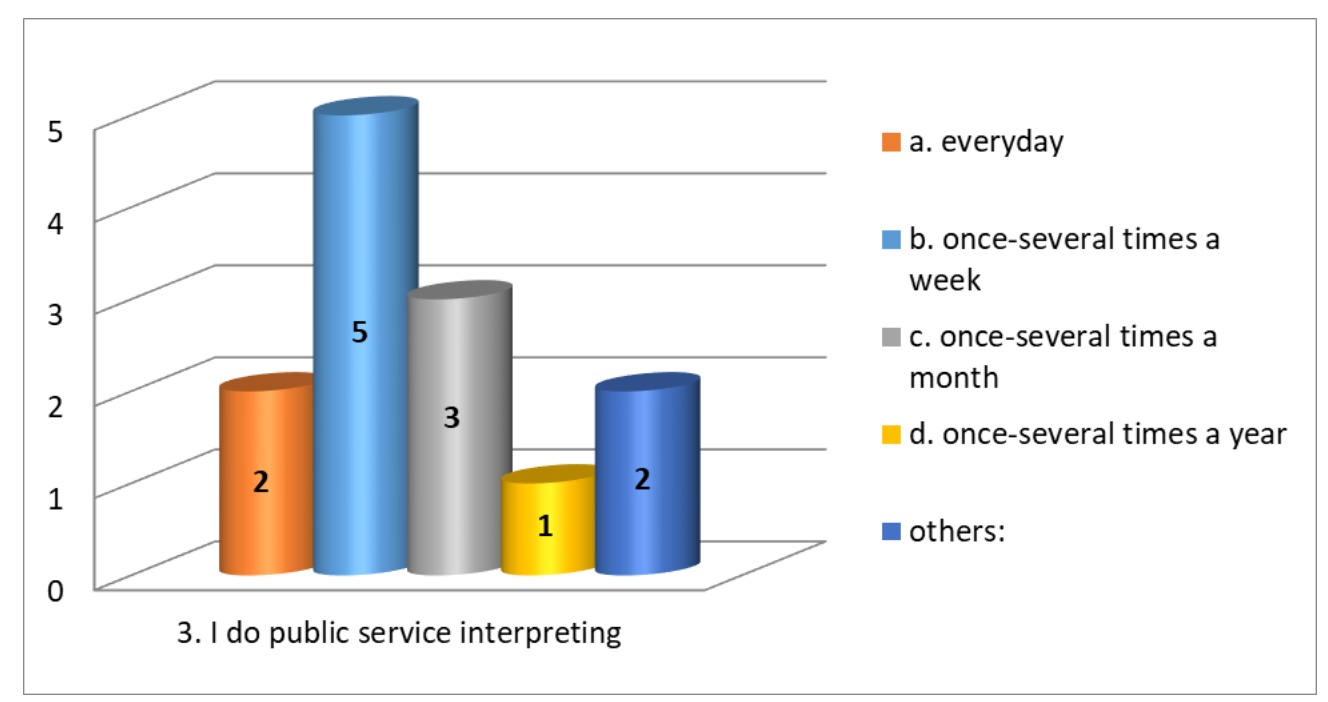

Figure 3. Frequency of doing public service interpreting

\subsection{Participants' need for training}

As regards the attendants' level of satisfaction, they were asked to indicate a corresponding mark on a six-point scale where 1 meant the lowest, and 6 the highest level of satisfaction. In particular, when asked if the topic of the workshop was new to them, 2 respondents indicated '2', 1 respondent indicated ' 3 ', 4 respondents indicated '4', 3 respondents indicated ' 5 ', and also 3 indicated ' 6 ' (see Figure 4).

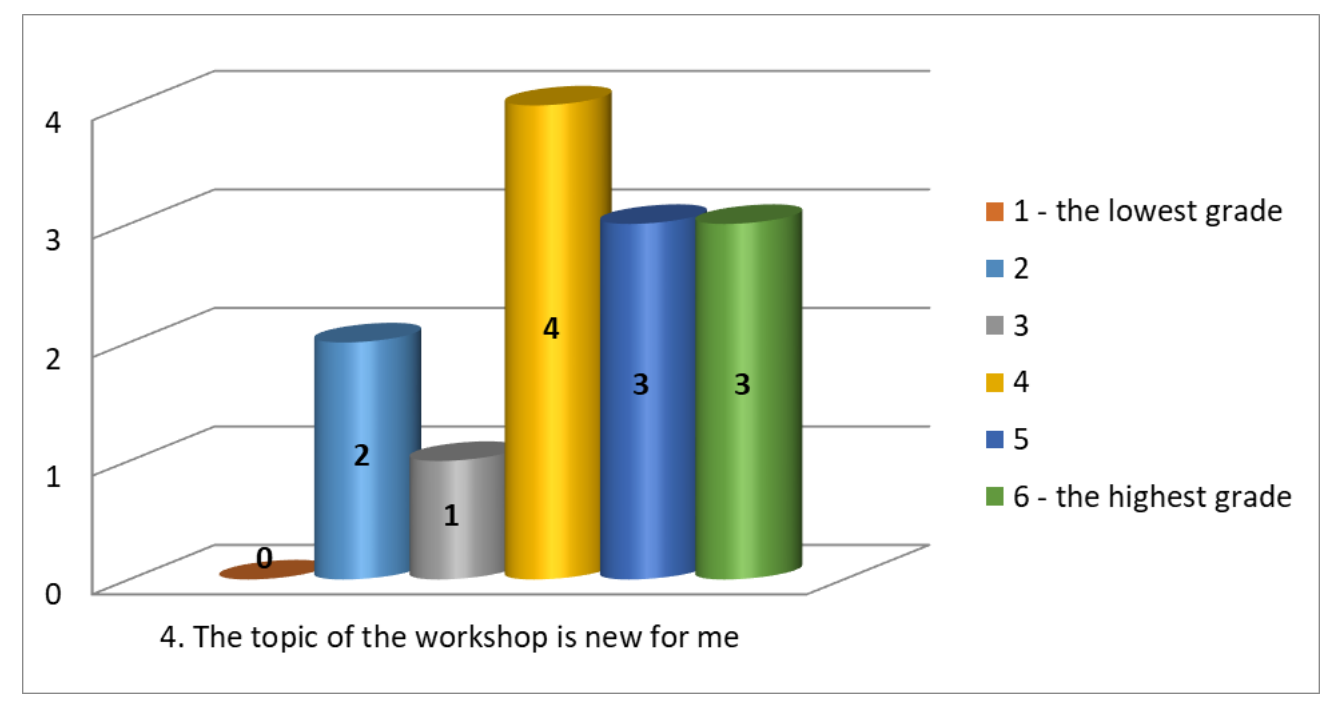

Figure 4. Assessment of the topic of the workshop as new 
When asked if the topic of the workshop was interesting, 1 respondent indicated ' 4 ', 6 indicated '5', and also 6 indicated ' 6 ' (see Figure 5).

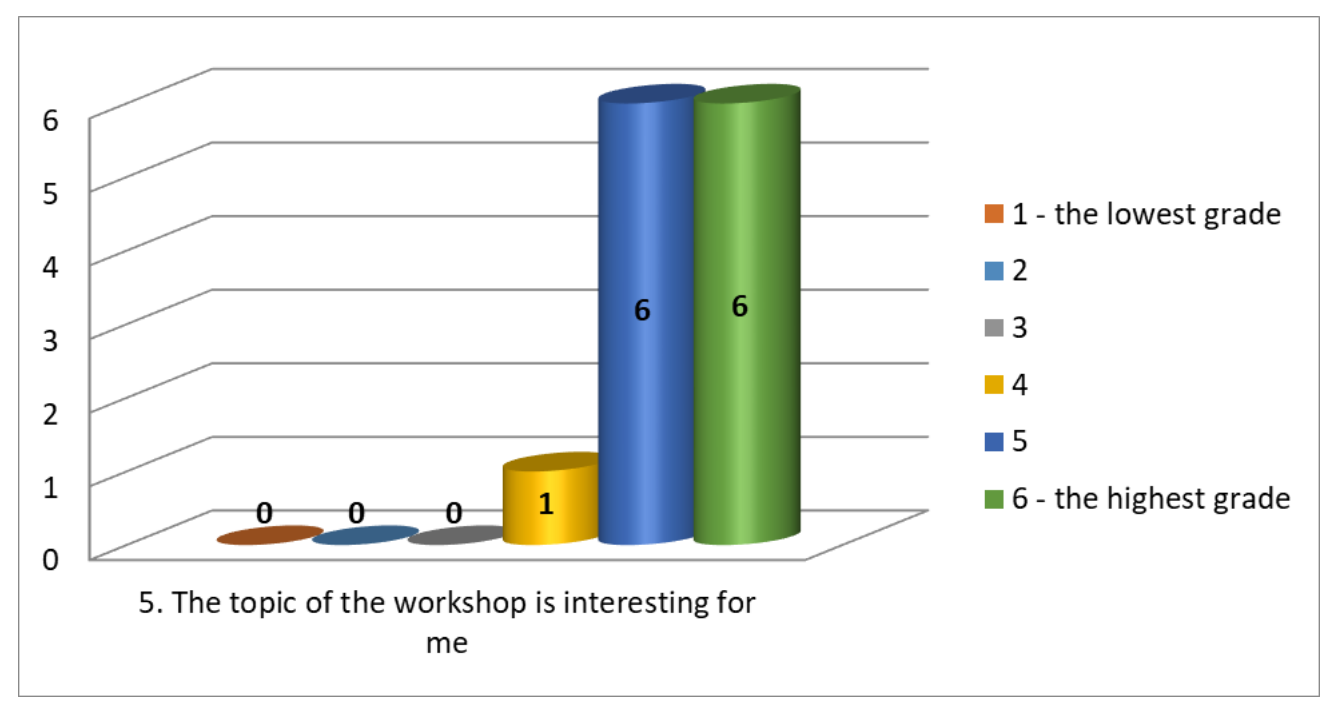

Figure 5. Assessment of the topic of the workshop as interesting

The two groups of responses may serve as an apt illustration for the point of departure of our research, suggesting the low level of respondents' familiarity with the topic of strategies and techniques in bilateral interpreting and the resulting need to expand their knowledge in this area.

Moreover, to the question about the usefulness of information obtained during the workshop in providing interpreting services, 1 respondent indicated ' 3 ', 1 respondent indicated '4', 3 respondents indicated ' 5 ', and 7 respondents indicated '6' (see Figure 6).

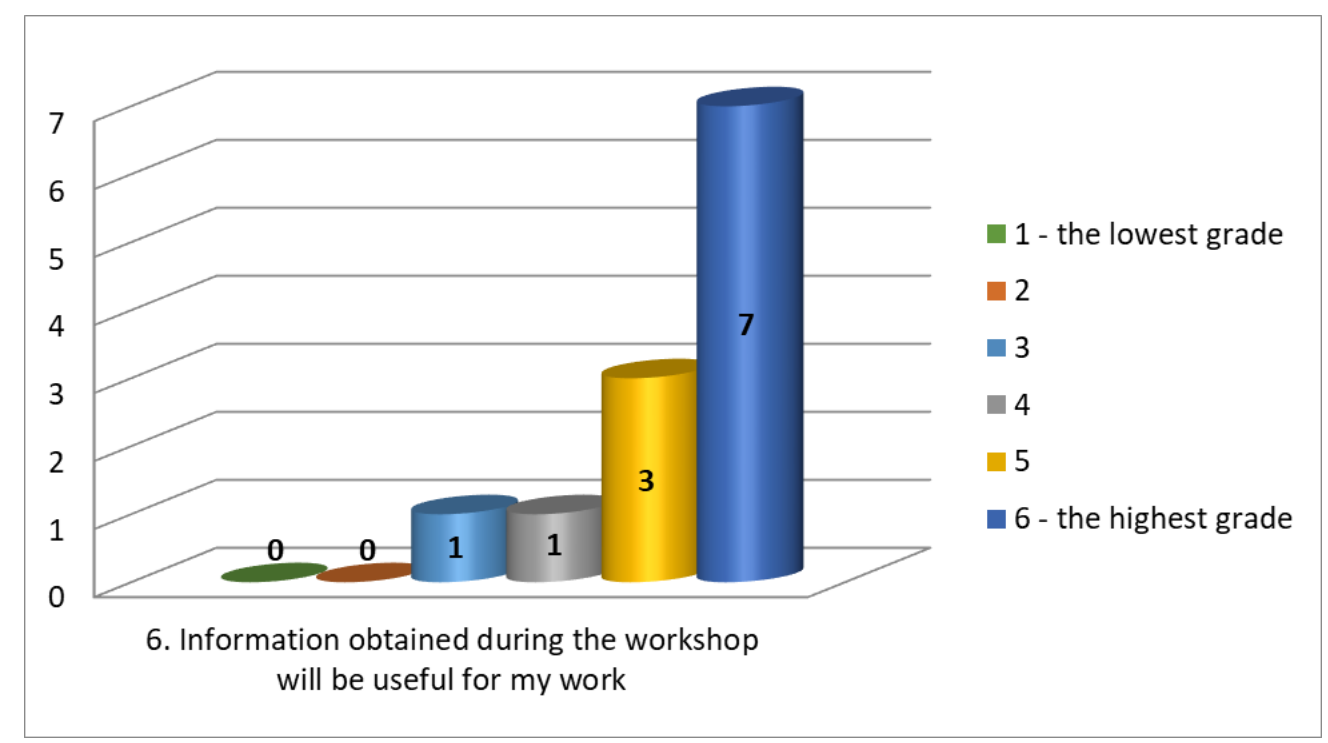

Figure 6. Information obtained during the workshop will be useful for my work 
When referring to the need to have further training sessions on the topic, out of all the 13 respondents, 6 indicated ' 4 ', 2 indicated '5', and 3 indicated '3' (see Figure 7).

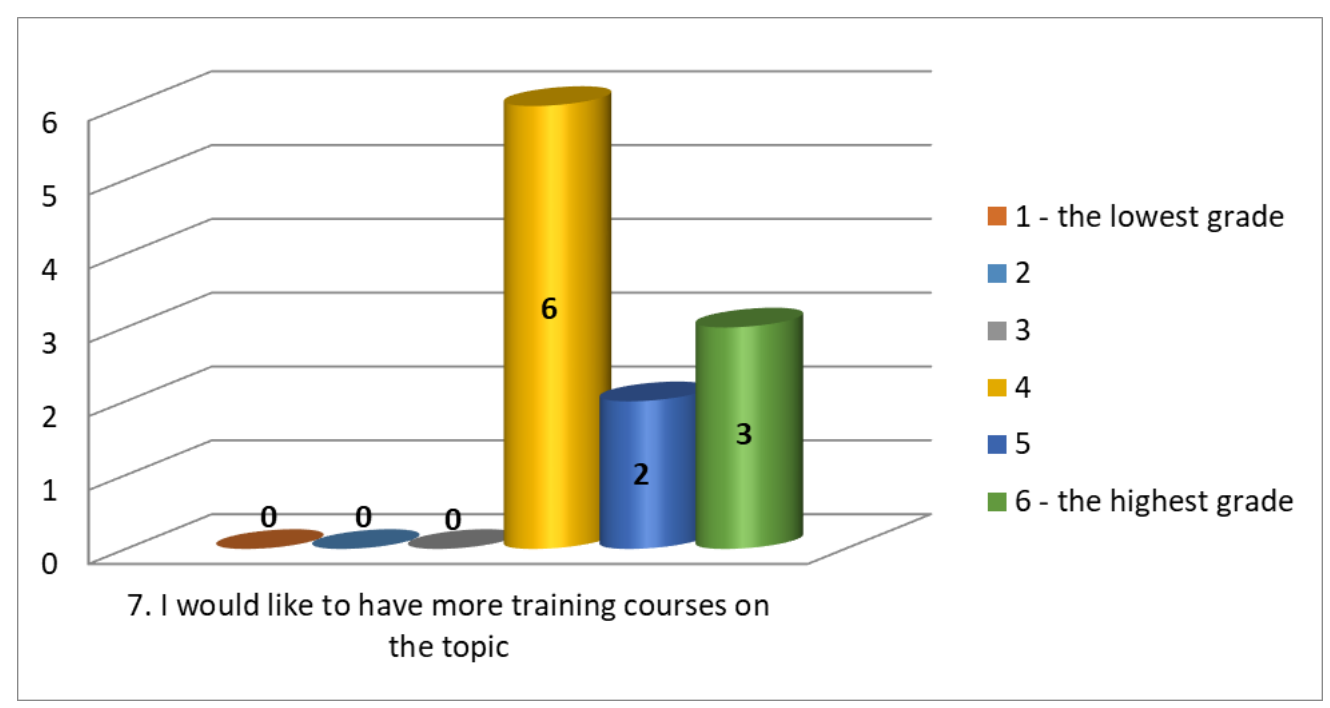

Figure 7. I would like to have more training courses on the topic

In general, the attendants expressed their interest in the training sessions already provided and in possible future workshop. In particular, they indicated the following areas of interest: practical activities; comparative analysis of spoken and sign language interpreting techniques; exchange of experience between colleagues who are sign language interpreters; interpreting cultural elements; solving problems faced by public service interpreters.

\subsection{Techniques applied by PJM interpreters}

Furthermore, the respondents were asked about techniques they apply as PJM interpreters. As regards close renditions, 6 respondents applied close renditions, 1 did not apply close renditions, while 6 respondents said that it depends (see Figure 8). 


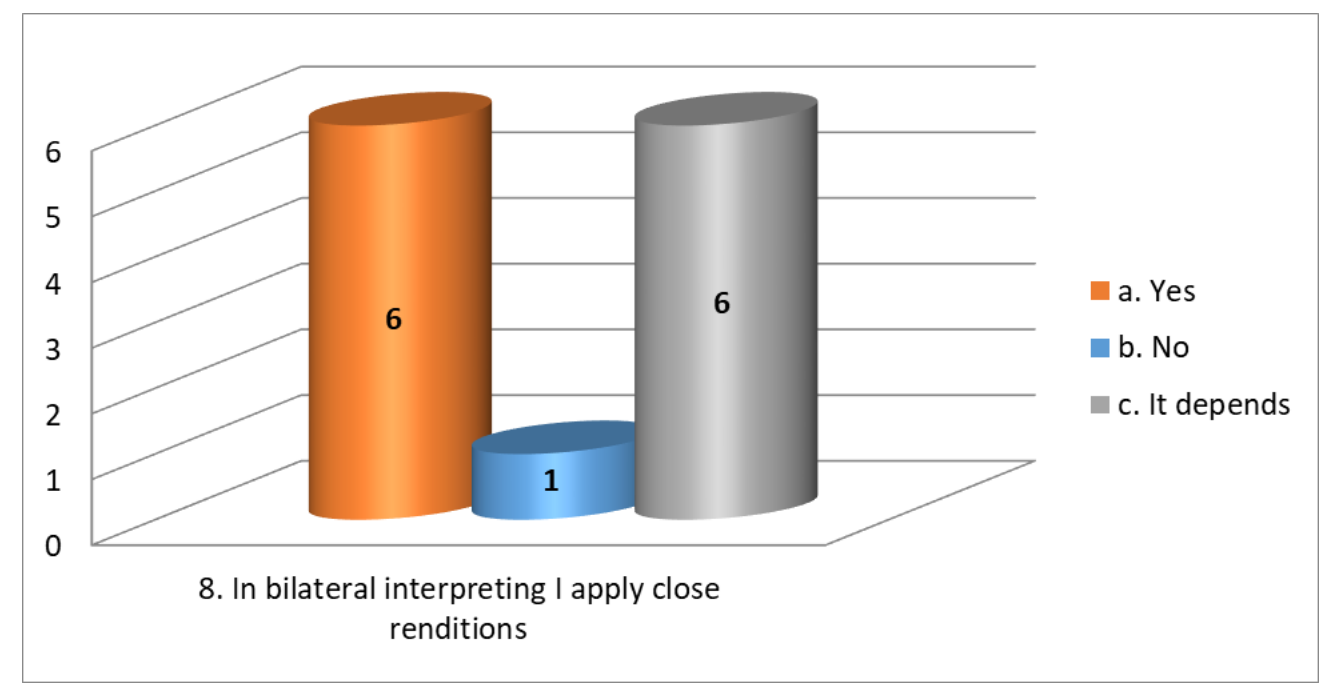

Figure 8. Close renditions

Those who replied that they apply close renditions commented that: all the information provided by primary speakers is important; accurate interpreting between spoken and sign language is not a problem; only close renditions are consistent with professional ethics. The only respondent who indicated that he/she does not apply close renditions explained that such a technique is impossible in sign language. The respondents who maintained that the use of this technique "depends", further said that it depends on the setting (courtroom/police station/prosecutor's office/doctor's office/other less formal); on the primary speakers' attitudes (they sometimes ask for 'word by word' interpreting, and sometimes for transmitting 'more or less' what the other party is saying, only the most important information); and on the speaker's pace.

As regards extended renditions, 4 respondents indicated that they apply them, 9 respondents said that it depends, and there were none who did not apply such a technique (see Figure 9). 


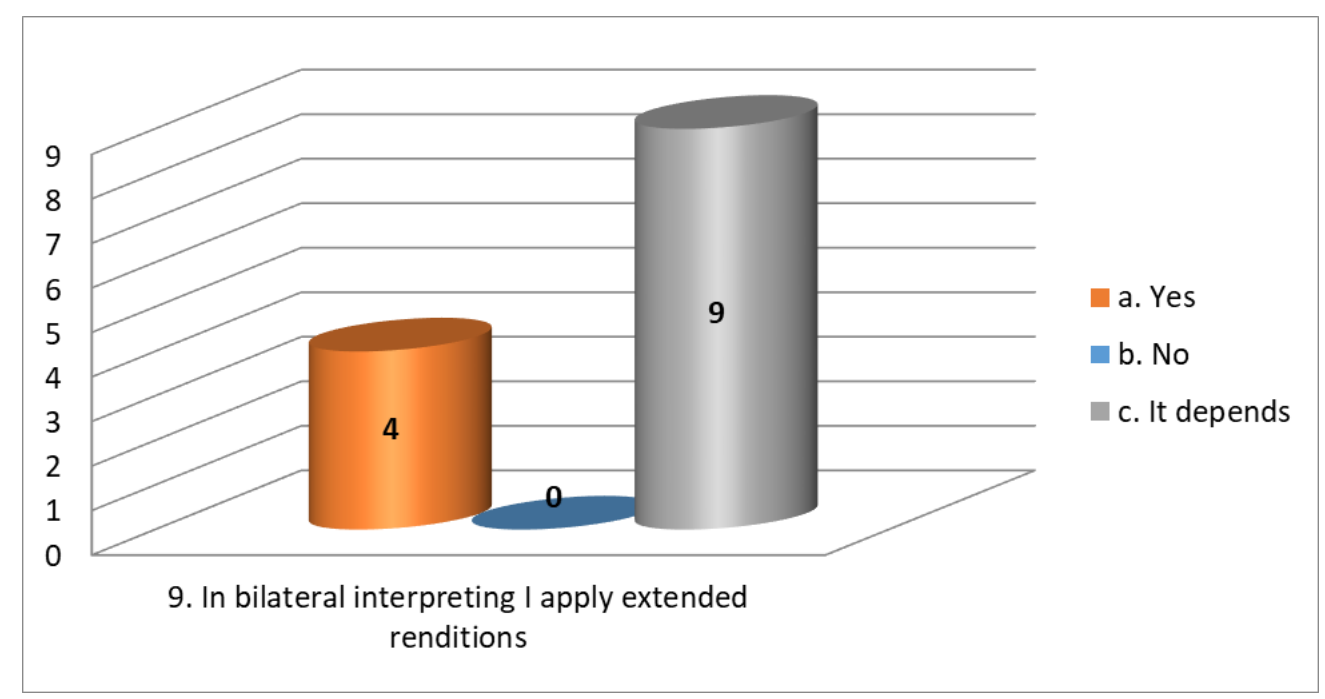

Figure 9. Extended renditions

Those who applied extended renditions commented that in their opinion the information added enhances communication and contributes to better understanding of interlocutors. The respondents who maintained that the use of this technique depends, further said that it depends on the setting (court/police/prosecutor's office/at the surgery/ other less formal) and on the interlocutors' attitudes (they sometimes ask the interpreter to translate 'word by word', and sometimes 'more or less', only the most important information). The fact that none of the respondents declared that they had not deployed extended renditions appears to correspond with the results of the abovementioned observations, namely that some of the extensions that appear in PJM interpreting are necessitated by deaf interlocutors' lack of access to certain auditory information accompanying interaction with hearing interlocutors. Consequently, the information must be provided by the interpreter.

As regards reduced renditions, only 1 respondent applied them, 4 did not, while 8 respondents said that it depends (see Figure 10). 


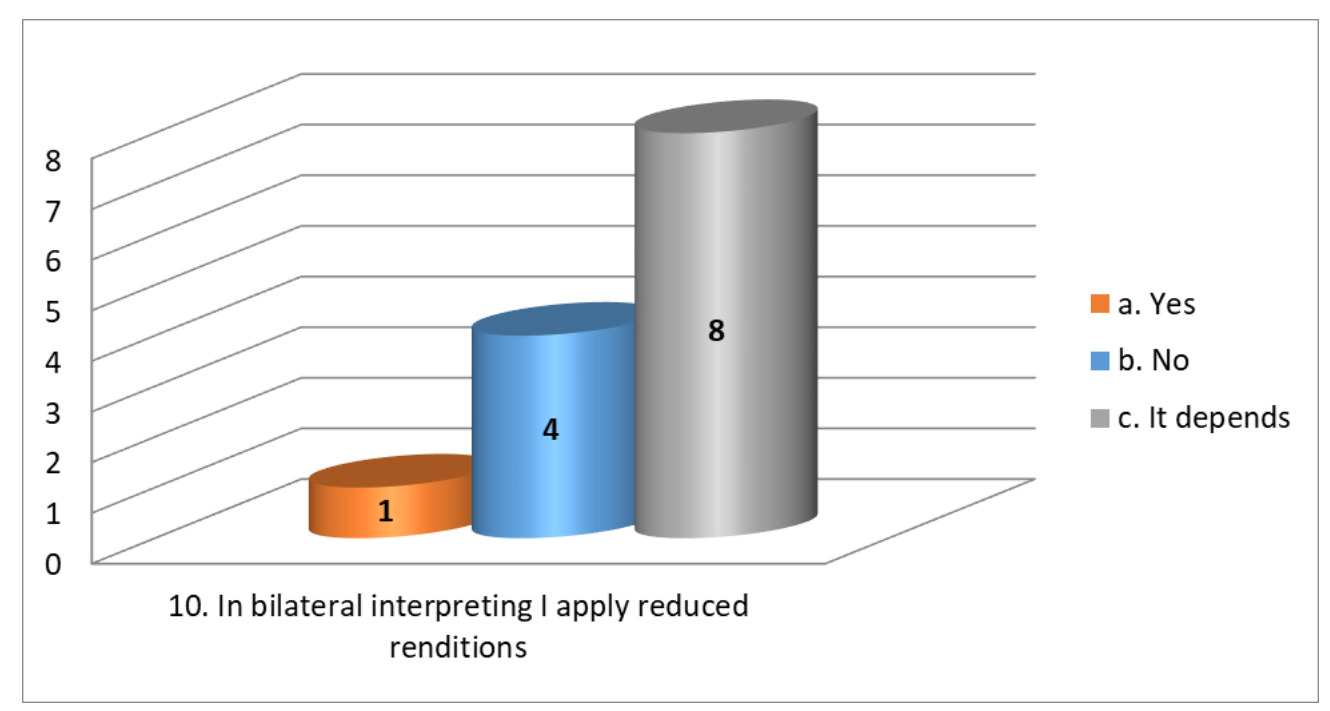

Figure 10. Reduced renditions

The respondent who admitted that he/she applied reduced renditions commented that their use is justified in the case of a lack of time. Those who indicated that they do not apply this technique said that it is their obligation to transfer all the information contained in the original message and that reduced renditions are contrary to the ethics. The respondents who maintained that the use of this technique depends, further said that it depends on the setting (court/police/prosecutor's office/at the surgery/ other less formal) and on the interlocutors' attitudes (they sometimes ask the interpreter to translate 'word by word', and sometimes 'more or less', only the most important information); on the speaker's pace; and on the impact of the reduced information on understanding the context.

As regards substituted renditions, 3 respondents applied them, 10 indicated that it depends, while there was none who would not apply such a technique (see Figure 11).

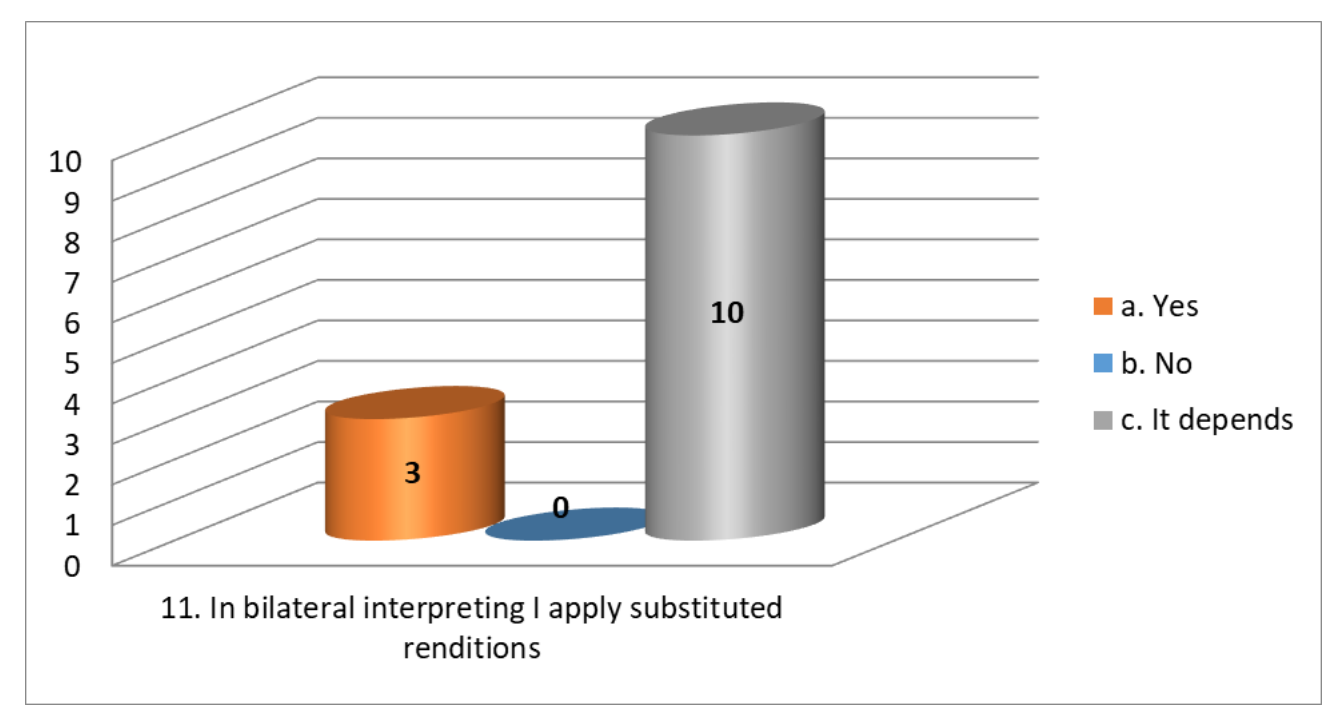

Figure 11. Substituted renditions 
The respondents who admitted that they applied substituted renditions said that: sometimes information needs to be enriched with an explanation, while on other occasions it can be omitted, e.g. when the context is already known to the interlocutors; 1 respondent indicated that the interpreter is a rightful participant of the act of communication and has the right to apply both techniques, depending on the needs. The respondents who maintained that the use of this technique depends, further said that it depends on the setting (court/police/prosecutor's office/at the surgery/ other less formal) and on the interlocutors' attitudes (they sometimes ask the interpreter to translate 'word by word', and sometimes 'more or less', only the most important information); on the speaker's pace; and on the deaf client (it may be assumed here that what was meant was the deaf person's contextual knowledge, experience or lack of thereof in communicating via the interpreter, their knowledge of Polish etc.).

As regards summarized renditions, only 1 respondent applied them, 4 did not, while 8 respondents said that it depends (see Figure 12).

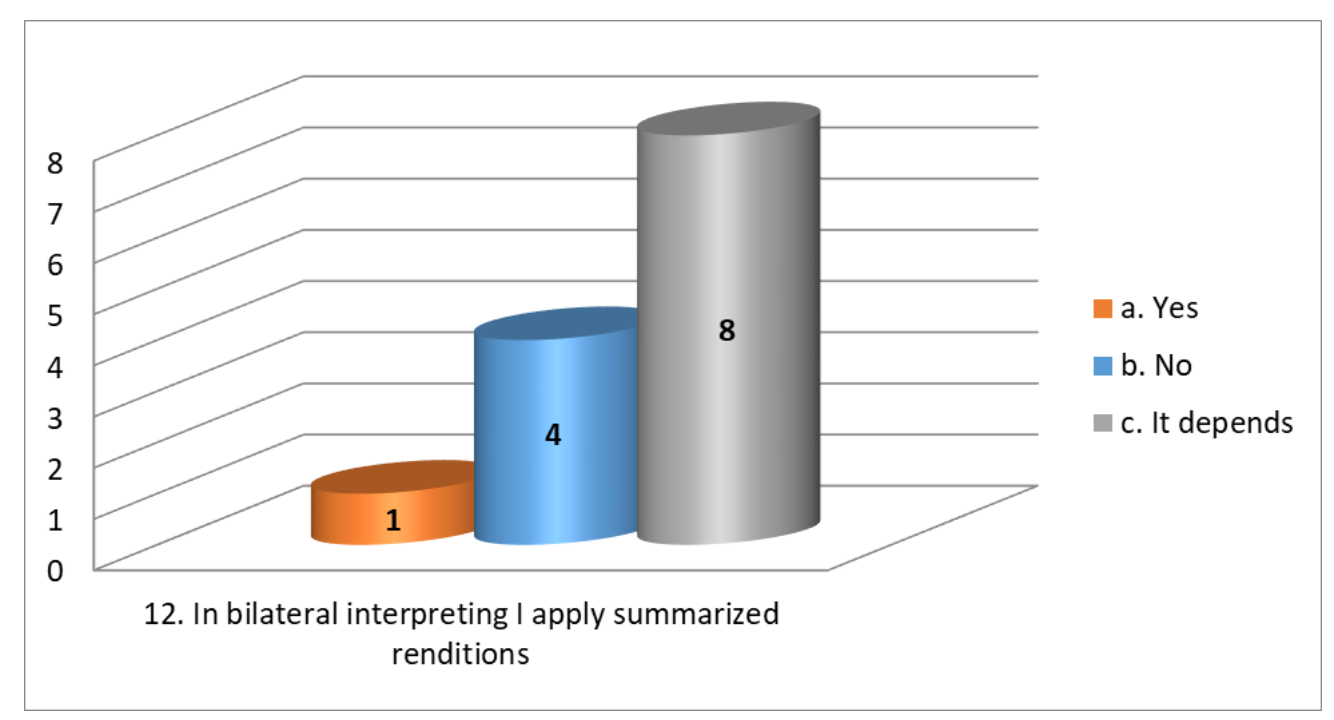

Figure 12. Summarized renditions

The respondent who admitted that he/she applied summarized renditions commented that it was in the event of a lack of understanding of an original message. Those who indicated that they do not apply this technique said that it is their obligation to transfer all the information contained in the original message and that summarized renditions are contrary to ethics. The respondents who maintained that the use of this technique depends, further said that it depends on the setting (court/police/prosecutor's office/at the surgery/ other less formal) and on the interlocutors' attitudes (they sometimes ask the interpreter to translate 'word by word', and sometimes 'more or less', only the most important information); and on the speaker's pace. 
As regards two-part or multi-part renditions, 6 respondents applied them, 1 respondent admitted not to use them, while 6 others said that it depends (see Figure 13).

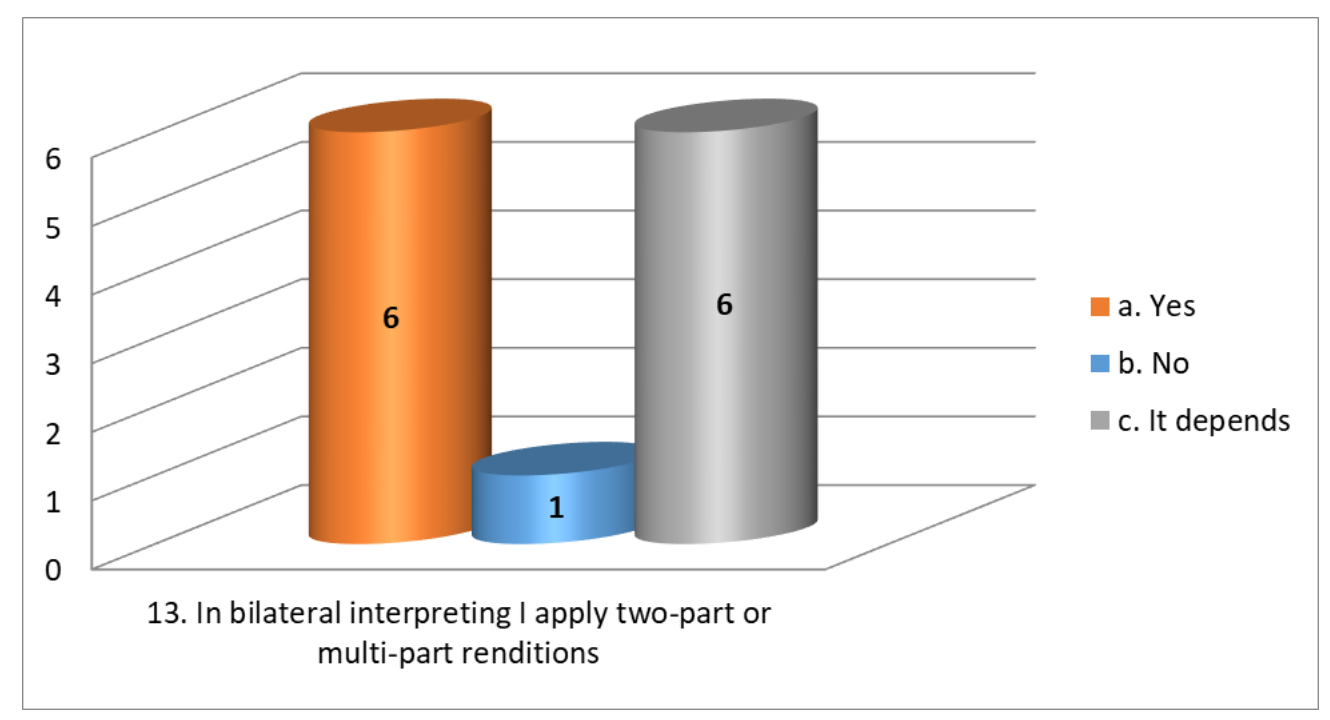

Figure 13. Two-part or multi-part renditions

The respondents who admitted that they applied two-part or multi-part renditions commented that, first, their use is justified in the case of long and convoluted original messages and therefore shorter statements or utterances are better understood for interlocutors, and secondly, the interpreter is a rightful participant of the act of communication and has the right to apply this technique. The respondent who maintained that he/she did not apply two-part or multi-part renditions admitted not to know such a technique. Those who indicated that the use of this technique depends, further indicate that it depends on the setting (court/police/prosecutor's office/at the surgery/ other less formal) and on their subjective assessment of their skills (e.g. ability to memorize the train of thought of the interlocutor in their long turns). It may be stipulated that the use of two-part or multi-part renditions may result from interpreters' insufficient lag time that often leads either to more literal renditions or to higher number of semantic chunks in the target language.

As regards non-renditions, 6 respondents indicated that they applied them, 7 respondents said that it depends, while there was none who did not apply such a technique (see Figure 14). 


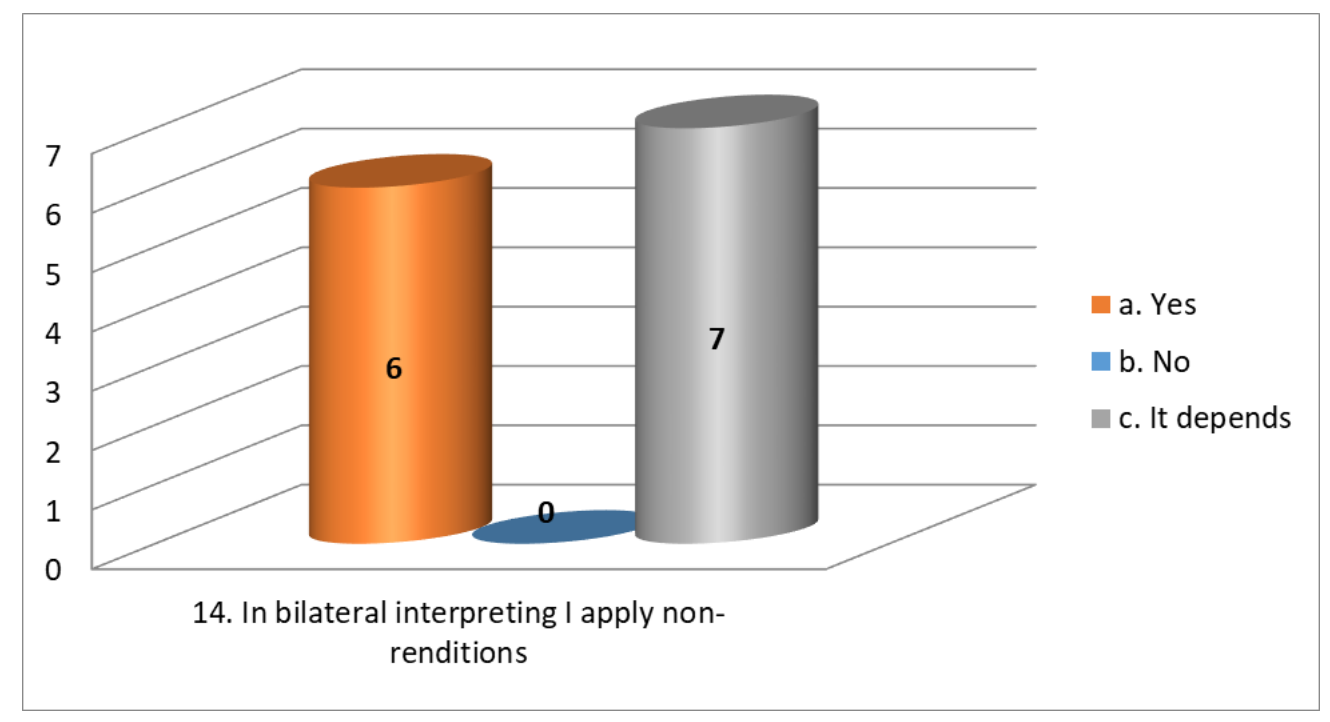

Figure 14. Non-renditions

Those who applied non-renditions commented that they sometimes needed to inquire the interlocutors about some details or ask for repeating the information which was a condition of providing interpreting; the interpreter is a rightful participant of the act of communication and has the right to ask additional questions, express requests for repeating or speaking slowly; also that such a technique is applied when the interpreter corrects their error while simultaneously confessing that such error took place. The respondents who maintained that the use of this technique depends, further said that it depends on the setting (court/police/prosecutor's office/at the surgery/ other less formal) and on the interlocutors (sometimes non-renditions are needless, while on other occasions it is necessary to continuously ask for repetition, speaking slowly, etc.). Non-renditions that were observed during the role-plays demonstrated that some of them are strongly connected with the specificity of sign language interpreting, particularly with the need of the signers to maintain almost ceaseless eye contact with each other. This usually requires the interpreter to take appropriate position, either seating or standing, which, in turn, needs to be negotiated with the hearing party.

As regards zero renditions, 7 respondents indicated that they do not apply them, 6 respondents said that it depends, while there was none who would apply such a technique (see Figure 15). 


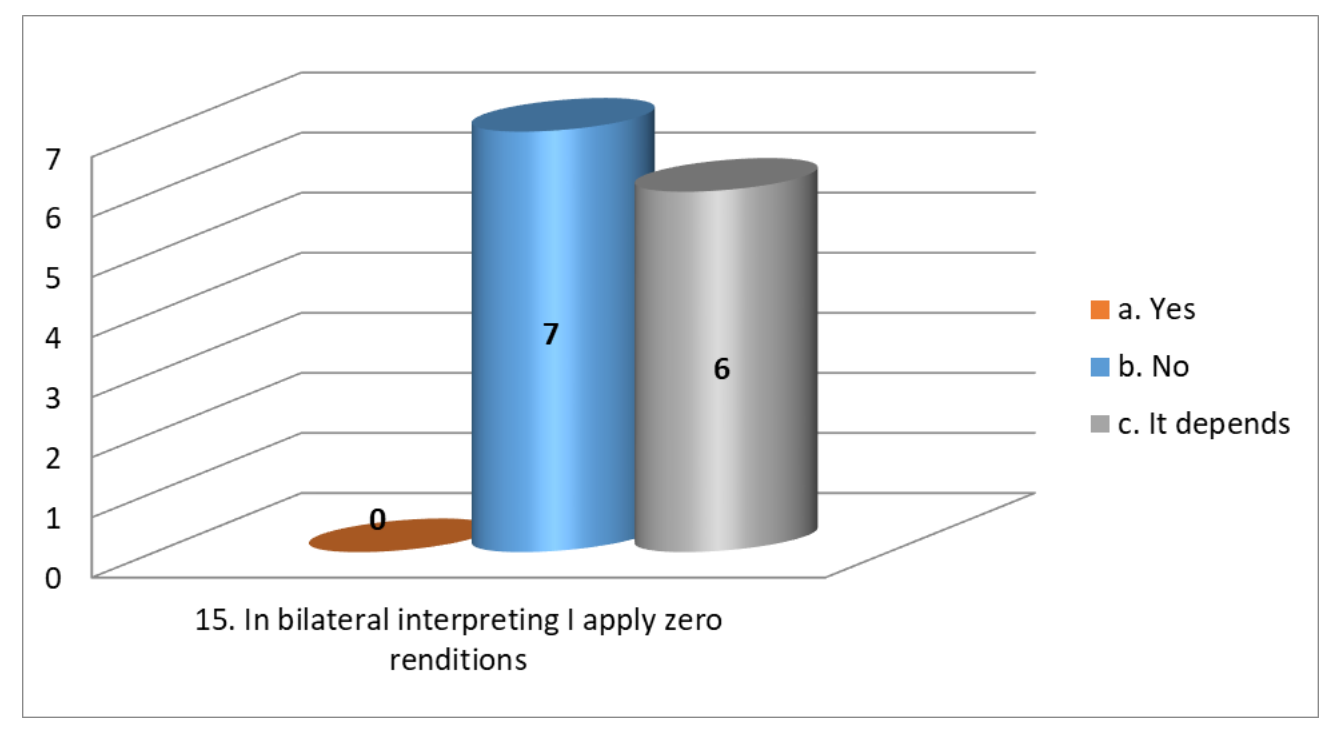

Figure 15. Zero renditions

Those who indicated that they do not apply zero renditions say that it is their obligation to transfer all the information contained in the original message and that zero renditions are contrary to ethics; there was also 1 respondent who admitted that he/she had never used this technique (therefore it is not unlikely that he/she may deploy it). The respondents who maintained that the use of this technique depends, further said that it depends on the setting (court/police/prosecutor's office/at the surgery/ other less formal) and on the interlocutors' attitudes (they sometimes admit that the interlocutor - only the children - should not hear vulgar expressions). As demonstrated by the abovementioned observations, the deployment of zero renditions may necessarily not be a fully conscious technique. It may well be a result of insufficient skills in managing the flow of communication (turn-taking).

\section{Conclusion}

The mixed-method approach enabled to comprehensively investigate the deployment of interpreting techniques by the interpreters of PJM. First, the observation has shown that some techniques are used by both spoken and sign language interpreters, but there are also those, which have been noticed either in spoken or sign language interpreting. In particular, it has been revealed that close, reduced, and zero renditions are applied similarly by both groups of interpreters. Some techniques, such as extended or non-renditions, are used in PJM interpreting taking PJM specificity into consideration. Substituted, summarized and two-part or multi-part renditions could not be found in the collected material though it does not mean that they are not used in PJM interpreting at all. In addition, it has been shown that contextualization of the 
techniques deployed is a common feature for both spoken and sign language interpreting. Furthermore, the observation has proved that the deployment of techniques by sign language interpreters is often intuitive; what is needed thus is an automation of a decision-making process.

The attendants' positive comments during and after both sessions concerning the idea of providing the PJM interpreters with an opportunity to improve their knowledge of interpreting techniques and to practice interpreting skills unequivocally testifies that there is a strong need for further training sessions dedicated to techniques in bilateral interpreting. The attendants expressed their interest in raising their awareness as to the ethical obligation of accurate interpreting and infringement of the principles of professional ethics in the event of zero renditions.

Moreover, the results of both the observations and the surveys have inspired many questions that need to be discussed in more detail, such as the use of fingerspelling - when it should be considered a technique ensuring precision and when it becomes the extended rendition; what are the causes of the extended renditions and by the same token, the reduced renditions; whether zero renditions appear proportionately in the interpreting of both interpreting parties' utterances (deaf and hearing) or one of the parties' utterances (which one?) are interpreted to a greater extent than the other's.

The above conclusions confirm a necessity to implement a project relating to further training and research, of which the discussed pilot project is a promising point of departure.

\section{References}

Biernacka, Agnieszka (2019) Interpreter Mediated Interactions of the Courtroom. A Naturally Occurring Data Based Study. Berlin: Peter Lang.

Bartłomiejczyk, Magdalena (2004) "Strategies of Simultaneous Interpreting and Directionality." Interpreting 8(2); 149-174.

Cokely, Dennis (1986) “Effects of Lag Time on Interpreter Errors.”, Sign Language Studies, $53 ; 341-375$.

Creswell, John W. (2014) Research Design. Qualitative, Quantitative, and Mixed Methods Approaches. London, Los Angeles, New Delhi, Singapore and Washington D.C.: SAGE Publications.

Dörnyei, Zoltan (2007) Research Methods in Applied Linguistics. Quantitative, Qualitative, and Mixed Methodologies. Oxford: Oxford University Press. 
Farris, Michael (1994) “Sign Language Research and Polish Sign Language.” Lingua Posnaniensis 36; 13-36.

Gile, Daniel (1995) Basic Concepts and Models for Interpreter and Translator Training. Amsterdam/Philadelphia: J. Benjamins.

Hale, Sandra (2008) "Controversies over the Role of the Court Interpreter.” [In:] Carmen Valero Garcés, Anne Martin (eds.) Crossing Borders in Community Interpreting. Definitions and Dilemmas. Amsterdam/Philadelphia: J. Benjamins; 99-121.

Kalata-Zawłocka, Aleksandra (2017) Społeczne i językowe konteksty tlumaczenia języka migowego w Polsce. Warszawa: Wydawnictwo Wydziału Polonistyki UW.

Kalina, Sylvia (1992) "Discourse Processing and Interpreting Strategies - an Approach to the Role of Teaching of Interpreting.” [In:] Cay Dollerup, Anne Loddegaard (eds.) Teaching Translation and Interpreting. Training, Talent and Experience. Amsterdam/Philadelphia: J. Benjamins; 251-257.

Koskela, Merja, Kaisa Koskinen, Nina Pilke (2017) "Bilingual Formal Meeting as a Context of Translatoriality." Target 29(3); 464-485.

Llewellyn-Jones, Peter (1981) “Simultaneous Interpreting.” [In:] Bencie Woll, Jim G. Kyle, Margaret Deuchar (eds.) Perspectives on British Sign Language and Deafness. London: Croom Helms; 89-104.

Napier, Jemina (2005) Sign Language Interpreting. Linguistic Coping Strategies. Gloucestershire: Douglas McLean.

Nicodemus, Brenda, Karen Emmorey (2013) "Direction Asymmetries in Spoken and Signed Language Interpreting.” Bilingualism: Language and Cognition 16(3); 624-636.

Riccardi, A. (1998) “Interpreting strategies and creativity”. Beylard-Ozeroff A (eds.)

Translator's Strategies and Creativity. Amsterdam/Philadelphia: J. Benjamins; 171-179. Sutton-Spence, Rachel, Bencie Woll (1999) The Linguistics of British Sign Language. An Introduction. Cambridge: Cambridge University Press.

Świdziński, Marek (1998) "Bardzo wstępne uwagi o opisie gramatycznym Polskiego Języka Migowego. Część I.” Audiofonologia 12; 69-83.

Tomaszewski, Piotr, Paweł Rosik (2003) „Czy Polski Język Migowy jest prawdziwym językiem?” [In:] Marek Świdziński, Tadeusz Gałkowski (eds.) Studia nad kompetencja językowa i komunikacja niestyszacych. Warszawa: Uniwersytet Warszawski: Wydział Polonistyki, Wydział Psychologii, Polski Komitet Audiofonologii, Instytut Głuchoniemych im. ks. Jakuba Falkowskiego; 109-143.

Tryuk, Małgorzata (2007) Przekład ustny konferencyjny. Warszawa: Państwowe 
Wydawnictwo Naukowe.

Tryuk, Małgorzata (2010) "Strategies in Interpreting: Issues, Controversies, Solutions".

Lingwistyka Stosowana/Applied Linguistics/Angewandte Linguistik 2; 81-194.

Wadensjö, Cecilia (1998) Interpreting as Interaction. London, New York: Longman.

\section{Internet sources consulted}

ISO 13611: 2014 Interpreting - Guidelines for community interpreting. https://www.iso.org/standard/54082.html (date of access: April 11, 2019).

Kodeks zawodowy thumacza przysięgłego http://tepis.org.pl/wp-content/uploads/Kodekszawodowy-t\%C5\%82umacza-przysi\%C4\%99g\%C5\%82ego-2018.pdf (date of access: December 4, 2018).

Kodeks Etyczny Stowarzyszenia Tłumaczy Polskiego Języka Migowego http://nowy.stpjm.org.pl/wp-content/uploads/2016/11/kodeks.pdf (date of access: April 11, 2019).

Rozporządzenie Ministra Sprawiedliwości z dnia 24 stycznia 2005 r. o biegłych sądowych http://prawo.sejm.gov.pl/isap.nsf/DocDetails.xsp?id=WDU20050150133 (date of access: February 5, 2019).

Ustawa o zawodzie tłumacza przysięgłego z dnia 25 listopada 2004 r. (Dz.U. z 2015 r. Nr 487) https://bip.ms.gov.pl/pl/rejestry-i-ewidencje/tlumacze-przysiegli/ (date of access: July 7, 2019). 